\title{
PENYARINGAN INFORMASI DALAM PENGAMBILAN KEPUTUSAN DI KANTOR TATA RUANG KOTA MAKASSAR (STUDI KOMUNIKASI ORGANISASI)
}

\author{
Munawir Gay ${ }^{1}$, Sri Yuyun ${ }^{2}$,Masyhadiah ${ }^{3}$ \\ 1Prodi Ilmu Komunikasi , Fakultas Ilmu-ilmu Sosial dan lmu Pemerintahan \\ Universitas Al Asy"ariah Mandar \\ nawir1463@gmail,com \\ 2,3Prodi Ilmu Komunikasi, Fakultas Ilmu-ilmu Sosial dan Ilmu Pemerintahan \\ Universitas Al Asyariah Mandar \\ yuyunsri765@gmail.com, diahh22yellow@gmail.com
}

\begin{abstract}
ABSTRAK
Penelitaian ini bertujuan untuk mengetahui sistem penyaringan informasi, dan mejelaskan proses dalam pengambilan keputusan serta faktor- faktor yang mendukung sistem penyarigan informasi untuk pengambilan keputusan. Tipe penelitian ini adalah studi kasus (case study) dengan pendekatan penyaringan informasi dalam pengambilan keputusan di Kantor Dinas Tata Ruang dan Bangunan Kota Makassar. Metode pengumpulan data yang di gunakan adalah observasi, wawancara, dokumentasi, dan studi kepustakaan. Data analisis domain dan taksonomi untuk mendiskripsikan hasil penelitian. Hasil penelitian menunjukkan bahwa penyaringan informasi digunakan sebagai bahan dalam pengambilan keputusan, kebijakan, dan pelaksanaan kegiatan internal maupun eksternal Dinas Tata Ruang dan Bangunan. Selain itu, penyaringan informasi adalah acuan dasar untuk menjalankan pengambilan keputusan sekaligus bahan pengembangan keputusan-keputusan yang sifat regulasi. Sementara itu, proses komunikasi dalam pengambilan keputusan dalam bentuk rapat pengkomunkasian informasi dilakukan dalam bentuk pelaporan dan informasi rutin. Selanjutnya, faktor-faktor yang mendukung sistem penyatingan informasi dalam pengambilan keputusan adalah ketersedian data dan informasi, keterbukaan dalam proses penyaringan informasi dalam pengambilan keputusan, pengusaan ruang lingkup permasalahan, tanggung jawab terhadap tugas yang diberikan, komunikasi yang terjalin dari internal dan eksternal organisasi dari keselurh unit kerja
\end{abstract}

Kata Kunci: Penyaringan Informasi

\section{ABSTRACT}

This Study aims to review infromation filtering system, explain the procec of decision making, and find out the factors that support infromation filtering in the process of the decision making.The research was conducted as a case study at the office of Spatial Planning and Building Service, Makassar. The data were colected through observations, interviews docomentation, and library research, and were analysed by using the qualitative analysis with the spradly model, analysis of domain and tasxonomi to describe the result of the study. The result several that information filtering is used in making decisions, estabilishing policies, and conducting internal and extenal activities at the Office of Spatial Planning and Building Services, Makassar, Information filtering is also used as a besic referance in making decisions and developing regulations. Communication accure in meetings, and information is given in reports and reutine information channel. Futhermore, the factor that support the information filtering system are : availability of data information, the open process information filtering in making decisions, good knowledge about the scope of the problem, responsibility for assigned tasks, and communication in the organisation (internal and external) and all working units.

Key Word: Information Filtering 


\section{PENDAHULUAN}

Hampir semua studi tentang manusia dan kehidupannya selalu berhubungan dengan komunikasi. Komunikasi memang selalu ada pada setiap kegiatan manusia. Banyak ahli yang membahas bidang sosial yang selalu menyentuh bidang komunikasi baik yang di tempatkan sebagai pusat kajian maupun hanya sebagai salah satu aspek atau sudut pandang saja. Artinya, hampir semua kajian sosial selalu melibatkan komunikasi sebagai salah satu komponennya. Misalnya, komunikasi di bidang Tata Ruang dan Bangunan, sosial kemasyarakatan, informasi, manajemen dan semua bidang ilmu lainnya. Dipihak lain, jika orang berbicara komunikasi, tentu menyangkut informasi didalamnya. Sebab pesan-pesan komunikasi yang digagaskannya adlah informasi memang selalu ada pada setiap peristiwa komunikasi Irra 2014 : 26. Untuk lembaga misalnya, bukan segi-segi bentuk dan struktur lembaga tersebut yang di utamakan pembahasannya, melainkan lebih banyak bentuk komunikasi dan bagaimana yang sering terjadi didalam, proses informasinya, bagaimana interaksi antara orang-orang yang ada didalamnya, serta efek apa saja yang menjadi akibatnya, serta tujuan akhir dari penggunaan komunikasi dalam informasi di lembaga tersebut di targetkat untuk apa

Pada organisasi atau lembaga pemerintah, pembahasan yang terpenting adalah bagaimana pola hubungan antara orang-orang yang ada didalamnya, serta aspek-aspek lain dari pola kehidupan manusia dalam lembaga atau struktur sosial dimaksud, apakah di dalamnya ada keteraturan tujuan dan proses Suswanto 2014 : 56.. Semua aspek sosial pada struktur-struktur dalam masyarkat, terutama yang banyak menghimpun, mengolah dan pelayan informasi, akan di ketahui dengan pedekatan teori. 2014 : 56. Bahwa informasi adalah bahan-bahan yang mengandung unsur-unsur yang dapat di komunikasikan, fakta-fakta, data atau segala sesuatu yang dapat menerangkan suatu hal dengan sendirinya atau melalui sesuatu yang telah atur melalui bentuk dokumen, file, laporan, buku,diagram, peta, gambar, foto, film, visual, rekaman suaru, rekaman melalui komputer dan metode lain yang dapat di tampilkan. Jadi bisa penulis simpulkan bahwa informasi adalah sebagai bahan atau bentuk pemahaman yang disampaikan sebagai pesan kepada pihak-pihak lain untuk di pahami dan menjadi pertimbangan dlam pengambilan keputusan (merumuskan kebijakan) maupun untuk sekedar di ketahui. Dilihat dari sudut manajerial, semua langkah yang biasa di tempuh dalam proses manajemen hanya dapat dilakukan dengan efektifitas tinggi apabila didasarkan pada informasi. Proses informasi mencakup penentuan tujuan, penentuan sasaran, perumusan dan penenttuan strategi, perencanaan, penyusunan program kerja, pengorganisasian, penggerak sumber daya manusia, penyelengaraan kegiatan operasional, pengawasan, penilaian serta penciptaan dan penggunaan sistem umpan balik.

Upaya yang dilakukan, Pemerintah Kota Makassar dalam menghadapi kendala pemberian Izin Mendirikan Bangunan dalam rangka pemeliharaan Tata Ruang Kota Makassar adalah dengan melakukan penyuluhan dan informasi masalah IMB dan Tata Ruang Kota Makassar kepada masyarakat. Melakukan pelayanan informasi secara terpadu guna memberikan kemudahan kepada masyarakat. Dalam memperolah IMB. Dampak yang buruk adalah jika terjadi penurunan kepercayaan dari sistem informasi. Jika informasi yang dihasilkan dari pengolahan komunikasi tidak di percaya, berarti sistem komunikasi yang bersangkutan tidak dapat di gunakan dalam organisasi, karena dapat membahaykan proses pengambilan keputusan strategis bagi manajemen. Akibat yang fatal bila seorang pimpinan salah mengambil keputusan karena tidak akuratnya informasi yang di sajkan oleh sistem informasi (menyimpang dari data sebenarnya). Selain itu kelemahan penerapan sistem informasi yang kurang pas adalah terjadinya kelebihan informasi yang tidak di 
perlukan dalam organsasi, seperti dalam hal data entry. Sehingga bila dilahat dari kacamata manajemen hal ini tidak efisien dan membuang-buang biaya karena harus menggaji beberapa orang untuk memasukkan data yang sama. Dari penjelasan di atas, maka rumusan masalah penelitian adalah 1) Bagaimana sistem penyaringan informasi untuk penganbilan keputusan di Kantor Dinas Tata Ruang dan Bangunan Kota Makassar. 2) Bagaimana sistem penyaringan informasi untuk penganbilan keputusan di Kantor Dinas Tata Ruang dan Bangunan Kota Makassar?

\section{METODE PENELITIAN}

Jenis Penelitian adalah studi kasus (Case Study) dengan pendekatan penggunaan informasi dalam organisasi, yaitu berusaha mendeskripsikan mengenai penyaringan informasi dalam pengambilan keputusan. Penelitian ini menggunakan pendekatan kualitatif Sebagaimana jenis penelitian yang telah dikemukakan di atas, maka disain penelitian adalah penyaringan informasi dalam Pengambilan Keputusan dengan desain studi penelitian studi kasus. Penelitian ini berfokus pada permasalahan penyaringan informasi terhadappengambilan keputusan di Dinas Tata Ruang Dan Pemukiman Kota Makassar.

\section{HASIL DAN PEMBAHASAN}

Hasil penelitian dan pembahasan pada penelitian tersebut :

A. Penyaringan informasi untuk penganbilan keputusan di Kantor Dinas Tata Ruang dan Bangunan Kota Makassar. Wawacara mendalam dengan Kepala Dinas Tata ruang dan Bangunan Kota Makassar Ir. Andi Oddang Wawo, M.Sc. menjelaskan bahwa : Setiap pembangunan dan pengembangan bangunan khususnya berskala besar dibahas pada tingkat aspiraasi masyrakat dan DPR, Badan
Koordinasi Perencanaaan Pembangunan Daerah(BKPRD) yang anggotanya tersendiri instansi terkait sekertariatnya berada di BAPEDA Kota Makassar. Sedangkan pemberian IMB untuk bagunan, SPBU, perumahan diatas $5 \mathrm{Ha}$ harus dengan rekomendasi Walikota Makassar.

Hal yang sama di sampaikan .Sekertaris DTRB Kota Makasssar Sukri Hasanuddin menyatakan Proses penyaringan informasi di Tata Ruang sudah berstruktur, sesuai dengan fungsi, tugas dan tanggung jawab setiap Bidang dan Seksi. Seperti masalah administrasi IMB dan perhitungan di bagian Bidang Tata Bangunan. Kalau dalam kaitan dengan proses IMB, khususnya Bidang Tata Bangunan dominannya di teknis, dari pengukuran di lapangan, perletakan bangunan, jadi pada saat orang mengurus izin dan diproses ke administrasi izinnya terus dibawah ke atas ke bidang Tata Bangunan kemudian diproses untuk peninjauan lapangannya bahwa permohonan sudah sesuai dengan apa yang ada di lapangan, terus pelatakan bangunannya terhadap versi utamanya. Hasil data dan informasi tersebut menjadi bahan untuk pengambilan keputusan pemberian izin mendirikan. Selanjut di Sampaikan kepala bidan perizinan bangunan (IMB) Drs. Irwan R. Adnan, M.Si. Bahwa Seluruh perencanaan dan kegiatan yang berjalan di Kantor Dinas Tata Ruang dan Bangunan Kota Makassar berdasarkan informasi yang telah dianalisis dan dikembangkan berdasarkan kebutuhan perencanaann pembangunan daerah. Pernyataan tersebut dibenarkan oleh kepala bidan tata ruang Ir. H. Ahmad Husain, M.Si.. sebagaimana pernyataan berikut Benar, Proses penyaringan informasi di tata ruang berjalan secara terstruktur. Kaitan dengan proses IMB, khususnya bidang tata bangunan dominannya ke teknis, misalnya Ruko (Rumah Toko) secara administrasi harus sesuai keputusan Walikota No. 8 
Tahun 2008 mengenai penggunaan lahannya aspek bahwa lokasi tersebut bisa tidak dibangun kalo tidak karena berdasarkan keputusan Walikota itu sudah terbagi dari setiap ruas jalan peruntukan seperti perintis, sungai sadang, rapocini, untuk pettarani memang khususnyakantor. Setiap pembangunan ruko harus sesuai peraturan pemerintah yang membijaksanai termasuk perda no. 6 tahun 2006 mengenai rencana tata ruang wilayah, wilayah kota makassar dibagi atas 13 wilayah kawasan terpadu. Sedangkan pembangunan SPBU harus dilihat dari segi peruntukan dan kemudian diterbitkan rekomendasi peruntukan lahannya. Proses penyaringan informasi untuk Pengambilan Keputusan di Kantor Dinas Tata Ruang dan Bangunan Kota Makassar secara umum berawal dari penyaringan aspirasi masyarakat dan telah melalui persetujuan DPRD kota Makassar. Informasi tersebut dibahas dengan Kepala Dinas, Kepala Seksi, Kepala Bidang. Hasil pembahasan tersebut tetap memperhatikan hasil survey dilapangan.

Pada organisasi atau lembaga pemerintah, pembahasan yang terpenting adalah bagaimana pola hubungan antara orang-orang yang ada didalamnya, serta aspek-aspek lain dari pola kehidupan manusia dalam lembaga atau struktur sosial dimaksud, apakah di dalamnya ada keteraturan tujuan dan proses Suswanto (2019: 30). Semua aspek sosial pada strukturstruktur dalam masyarkat, terutama yang banyak menghimpun, mengolah dan pelayan informasi, akan di ketahui dengan pedekatan teori .Seluruh perencanaan dan kegiatan yang berjalan di Kantor Dinas Tata Ruang dan Bangunan Kota Makassar berdasarkan informasi yang telah dianalisis dan dikembangkan berdasarkan kebutuhan perencanaann pembangunan daerah. Penyaringan informasi dalam pengambilan keputusan, secara internal organisasi kuhusunya dinas tata ruang dan bangunan dilaksnakan berdasarkan permasalahan yang dihadapi. Data dan informasi diolah berdasarkan kondisi lapangan dan dibahas bersama dengan seluruh jajajran, Kepala Dinas, Kepala Seksi dan Kepala Bidan

B. Pengembalian Keputusan di Kantor Dinas Tata Ruang dan Bangunan Kota Makassar. Pengambilan keputusan adalah aspek yang paling penting dari kegiatan manajemen. Ia merupakan kegiatan sentral dari manajemen, merupakan kunci kepemimpinan atau sentral kepemimpinan, sebagai suatu karakteristik yang fundamental, sebagai jantug kegitan administrasi. Sesuatu yang kritis bagi tindakan administrasi, bahkan menurut Higgins dalam Irham(2012 : 20) bahwa pengambilan keputusan adalah kegiatan yang paling dari semua kegiatan karena didalamnya manajer terlibat, dan sekaligus merupakan pertanggung jawaban utama dari semua administrator melalui suatu proses tempat keputusankeputusan dibuat dan dilaksanakan.

Pengambilan keputusan mempunyai arti penting bagi maju mundurnya suatu organisasi, terutama karena masa depan suatu organisasi banyak ditentukan oleh pengambilan keputusan tepat. Pentingnya pengambilan keputusan dilihat oleh Rahmayadi (2014 : 40 ) dari segi kekuasaan untuk membuat keputusan, yaitu apakah mengikuti pola sentralisasi atau desentralisasi. Sementara itu, menurut Weber dalam Irham (2012) memberi perhatian pada pengambilan keputusan dari sudut kehadirannya, yaitru tanpa adanya teori pengambilan keputusan administratif kita tidak dapat mengerti, apalagi meramalkan tindakantindakan menajemen sehingga kita dapat menyempurnakan efektifitas manajemen. Pengambilan keputusan untuk organisasi akan dihadapkan pada pertanyaan, dalam bidang apa atau sektor apa yang mereka akan bergerak. Dengan kata lain, tujuan 
apa yang ingin dicapai dengan mendirikan organisasi, termasuk produk apa yang akan dihasilkan sehingga perencanaan mendukung upaya percapaian tujuan. Pada Umumnya tujuan organisasi adalah pertumbuhan dan perkembangan. Tidak ada pemimpin organisasi yang ingin melihat organisasi hanya jaya sementara waktu dan kemudian hilang dari peredaran. Meskipun benar tujuan jangka panjang organisasi ada kalanya ditentukan berdasarkan intuisi dan nalar, informasi tetap yang ingin dicapai. Hanya saja informasi yang relevan terbatas pada informasi yang sifatnya indikatif dan menunjukan berbagai kecenderungann yang diperkirakan akan terjadi serta berlanjut dalam kurun waktu yang panjang. Proses pengambilan keputusan dalam organisasi didasarkan beberapa kriteria dan alternatif-alternatif yang ada. Dalam prosesnya, suatu lembaga/instansi khususnya Dinas Tata Ruang dan Bangunan Kota Makassar, tidak terlepas dari yang mempengaruhinya yang meliputi keadaan internal organisasi. Keadaan eksternal organisasi, tersedianya data dan informsia yang diperlukan dan kecakapan pengambilan keputusan. Andi Oddang Wawo (Kepala DTRB Kota Makassar bahwa pengambilan keputusan sangat berhubungan dengan pengumpulan fakta. Data dan informasi dikumpulkan dari berbagai sumber kemudian dikaji dan analisa secara murni objektif untuk menjdai bahan pengambilan keputusan Hal sama di sampaikan oleh. Sekertariat DTRB Sukri Hasanuddin, SE, Msi, Data dan informasi sangat dibutuhkan dalam pengambilan keputusan misalnya : ada bangunan yang bermasalah dalam prooses pembangunannya, proses penyelesaiannya adalah kami kumpulkan data informasi, misalnya surat tanah/sertifikat tanah, atau terkadang bangunan sudah berdiri ada yang komplen, dan atau mengajukan permohonan IMB tidak melalui beberapa persyaratan. Proses penyelesaian, Dinas Tata Ruang hanyahanya melihat aspek legal kalau persyaratan dipenuhi kita proses IMBnya. Proses pengurusan IMB harus diketahui Lurah dan Camat karena yang mengetahui keabsahan tanah tersebut adalah Camat makanya formulir IMB harus ditanda tangan Lurah dan Camat."

\section{KESIMPULAN DAN SARAN}

Penyarigan informasi sangat berperan penting dan digunakan dalam menunjang kegiatan operasional untuk mendukug kebijakan dalam pengambilan keputusan dalam manajemen Dinas Tata Ruang dan Bangunan Kota Makassar,

Proses pengambilan di Dinas Tata Ruanga dan Bangunan dilakukan dalam bentuk penyaringan informasi dalam bentuik rapat internal , eksternal, pelaporan, arus informasi rutin (flow of information), masyarakat, LSM, Dinas terkait dan DPR

Berdasarkan atas temuan hasil penelitian ini, maka penulis memberikan saran-saran sebagai berikut :

1. Untuk mengatasi hambatan dalam penggunaan informasi dikalangan manajemen Dinas Tata Ruang Kota Makassar disarankan kepada pemimpin untuk lebih meningkatkan menerima masukan (input) dari berbagai sumber informasi, baik berupa sistem informasi computer dan humanware. Khusus untuk mengantisipasi hambatan tentang aturan yang bersumber dari Peraturan Daerah perlu disosialisasikan mengenai kebijakan dan peraturan tentang Tata Ruang kepada seluruh masyarakat.

2. Untuk meningkatkan proses pegambilan keputusan di Dinas Tata Ruang harus komunikasi dari internal dan eksternal organisasi. Dalam formulasi, sebuah 
rancangan keputusan dibahas dengan melibatkan berbagai pihak, baik yang mendukung maupun menentang kebijakan tersebut. Formulasi merupakan kompetensi untuk mencapai kesepakatan (compete for acceptance) dan memiliki karakteristik melibatkan berbagai macam kepentingan untuk didiskusikan dan sikompromikan. Berbagai pendapat yang muncul saling beradu argumentasi dan mempengaruhi satudengan yang lain dengan tujuan mencapaikesepakatan. Ketika rancangan kebijakan selesai diformulasikan, berarti telah melewati ajang yang tidah mudah dan bisa jadi berliku.

\section{DAFTAR PUSTAKA}

Chrisyanti Dewi, Irra, 2014, Sistem Informasi Sumber Daya Manusia, Penerbit, Bumi Askara, Jakarta

Fahmi, Ihram. 2011. Teori dan Teknik Manajem Pengambilan Keputusan, Penerbit PT. Gunung Agung, Jakarta

Khamsharial H. 2014, Komunikasi Organisasi Lengkap, Penerbit, PT. Gramedia. Jakarta

Suswanto H, 2019, Komunikasi Organisasi Kontemporer, Penertbit Simbiosa Rekatama Media, Bandung

Triyono, Agus Rahmayadi, 2012. Pengambilan Keputusan manajerial, Teori dan Praktek untuk Manajerial dan Akademisi. Penerbit, Salemba Empat,Jakarta 
